\title{
COMPARISON BETWEEN THE SHRIMP SPECIES RICHNESS (CARIDEA AND DENDROBRANCHIATA, DECAPODA, CRUSTACEA) OF THE SOUTH AND NORTH MID ATLANTIC RIDGE
}

\author{
Irene Azevedo Cardoso ${ }^{1, *}$, Tone Falkenhaug ${ }^{2}$ and Luiz, Fernando Loureiro Fernandes ${ }^{3}$ \\ ${ }^{1}$ Museu Nacional - Universidade Federal do Rio de Janeiro \\ Setor de Carcinologia, Departamento de Invertebrados \\ (Quinta da Boa Vista s/n, 20940040 Rio de Janeiro, RJ, Brasil) \\ ${ }^{2}$ Researcher at Institute of Marine Research (IMR), Flodevigen, Norway \\ (PO Box 1870 Nordnes 5817 Bergen, Noruega) \\ ${ }^{3}$ Universidade Federal do Espírito Santo - Departamento de Oceanografia e Ecologia \\ (Av. Fernando Ferrari, 514 29075-900 Vitória, ES, Brasil) \\ *Corresponding author: irenecardoso@mn.ufrj.br
}

http://dx.doi.org/10.1590/S1679-87592014060706201

\begin{abstract}
The Mid Atlantic Ridge (MAR) is a seamount chain extending for $60.000 \mathrm{~km}$, divided into south and north regions by the Equatorial Fracture which cuts across it. This latter has a maximum depth of $7,760 \mathrm{~m}$ and an average width of $19 \mathrm{~km}$. In this study we include data from the two cruises of the international project MAR-ECO, undertaken, respectively, one on the north and the other on the south MAR. Our main objective is to compare the species richness and species composition of pelagic and benthic decapod shrimps of these two areas to observe the patterns of their latitudinal distribution along the MAR. Using rarefaction methods, we obtained interesting results: the pelagic samples curve of the northern MAR is almost an asymptote, so we concluded that we are close to the true number of pelagic shrimp species for this region. The pelagic samples curve of the southern MAR had the greatest slope, so our conclusion is that we are still far from the true number of species for this region. A comparison of species richness at 12 samples (the smallest number of samples shared by both the surveys) revealed that the pelagic species richness was greater than the demersal, and that the northern MAR contained a larger number of species than the southern.
\end{abstract}

\section{RESUMO}

A Cordilheira Meso Atlântica (CMA) é uma cadeia de montes submersos com 60.000 km, dividida em região norte e sul, separadas pela Fratura Equatorial, que corta transversalmente a CMA. A Fratura Equatorial possui profundidade máxima de $7.760 \mathrm{~m}$ e largura média de $19 \mathrm{~km}$. Incluímos aqui dados de dois cruzeiros do projeto internacional MAR-ECO, um no norte e um no sul da CMA. Nosso principal objetivo é comparar a riqueza de espécies e a composição específica de camarões decápodes, pelágicos e bentônicos, dessas duas áreas para observar padrões de distribuição latitudinal ao longo da CMA. Usando métodos de rarefação, obtivemos resultados interessantes: a curva de amostras pelágicas da CMA norte encontra-se perto de uma assíntota, o que nos levou a concluir estarmos próximos ao número verdadeiro de espécies de camarões pelágicos nesta região. Por sua vez, a curva de amostras pelágicas da CMA sul possui uma inclinação muito forte, o que nos permitiu concluir que nessa região ainda estamos longe do número verdadeiro de espécies. Uma comparação da riqueza de espécies em 12 amostras (menor número de amostras compartilhado pelos dois cruzeiros) revelou que a riqueza de espécies pelágicas é maior do que a demersal, e que a CMA norte contém uma riqueza maior que a região ao sul.

Descriptors: Mid Atlantic Ridge, Decapoda, Caridea, Dendrobranchiata, Species richness, Specific composition, Distributional patterns.

Descritores: Cordilheira Meso-Atlântica, Decapoda, Caridea, Dendrobranchiata, Riqueza de espécies, Composição específica, Padrões de distribuição.

\section{INTRODUCTION}

The Mid Atlantic Ridge (MAR) is a topographically complex seamount chain that rises from $4000 \mathrm{~m}$ depth to peaks of just $500 \mathrm{~m}$ below the sea's surface. The ridge is $100-200 \mathrm{~km}$ wide and $60,000 \mathrm{~km}$ long. Seamounts are considered biologically distinctive habitats, mainly due to the formation of eddies of water associated with the 
upwelling of nutrient rich waters, leading to increased productivity. Food supplies in the open-ocean are restricted, so seamounts and mid-ocean ridges may serve as important habitats, feeding grounds and sites of reproduction for many deep-sea species (ROGERS, 1994).

Especially complex is the Equatorial Fracture (or Romanche Fracture) that extends transversally to the Mid Atlantic Ridge, from $2^{\circ} \mathrm{N}$ to $2^{\circ} \mathrm{S}$ and from $16^{\circ} \mathrm{W}$ to $20^{\circ} \mathrm{W}$. The fracture has a maximum depth of $7,760 \mathrm{~m}$, is $400 \mathrm{~km}$ long and has an average width of $19 \mathrm{~km}$ (DEMIDOV et al., 2006). It is a pathway for the Atlantic deep water masses that flow from west to east (FERRON et al., 1998). The Equatorial Fracture Zone is deep enough to allow significant eastward flows of Antarctic Bottom Water (ABW) from the Brazil Basin to the Sierra Leone and Guinea Abyssal Plains. After passing through the Equatorial Fracture Zone, the Antarctic Bottom Water spreads only to the southeastern and equatorial parts of the Atlantic. While flowing through the Equatorial Fracture Zone, the bottom-water properties are strongly modified due to intense vertical mixing (FERRON et al., 1998; DEMIDOV et al., 2006).

Given the region's great complexity, it may be expected to shelter a diverse deep-sea fauna. This expectation has prompted recent biological investigations on the southern Mid Atlantic Ridge, including the Equatorial Fracture area, within the framework of the international South Atlantic MARECO (SA MAR-ECO) project. This project is a spinoff of the MAR-ECO project (Patterns and Processes of the Ecosystems of the Northern Mid Atlantic Ridge), an element of the Census of Marine Life. The aim of MAR-ECO and SA MAR-ECO is to enhance our understanding of the occurrence, distribution and ecology of animals and animal communities along the MAR.

The aim of this study is to compare the shrimp fauna of the Northern and Southern MAR, and evaluate the effect of the Equatorial Fracture as a barrier.

The shrimp species analyzed herein are included in two crustacean groups: Suborder Dendrobranchiata, that is a relatively small and uniform decapod group with about 533 species (DE GRAVE; FRANSEN, 2011), all shrimp-like; and the Infraorder Caridea that is a highly diversified group among Decapoda, with about 3,438 species (DE GRAVE; FRANSEN, 2011). Many of its members are shrimp-like, but many variations of this basic shape can be observed to occupy a wide range of aquatic niches. In both groups most of the species are marine, pelagic or benthic, occurring from the coastal shore to the deep sea (BAUER, 2004; FARFANTE; KENSLEY, 1997).
The species richness and species composition of pelagic and benthic decapod shrimps from the northern and southern MAR are compared in order to observe the patterns existing in the latitudinal distribution of decapod shrimps along the MAR.

\section{Material And Methods}

We include here data from two cruises. The material from the Northern MAR was collected during the 2004 MAR-ECO expedition (from June 5 to August 5) on the R/V G.O. Sars, between the Azores and Iceland $\left(59^{\circ}-41^{\circ} \mathrm{N}\right)$. A total of 17 locations were sampled with bottom trawls (980 $3460 \mathrm{~m}$ depth) and 39 locations with pelagic trawls (0-2800 m depth) (Fig. 1). The bottom shrimp trawl was a Campelen 1800. Three different mid-water trawls were used for the pelagic sampling: a large "Egersund trawl", the "Åkra trawl" and the Macrozooplankton trawl. The study area on the northern MAR included three main domains defined by the distribution of water masses: the northern domain infuenced by the subpolar gyre; the SubPolar front, crossing the ridge at the Charlie Gibbs Fracture Zone; and the southern domain influenced by the subtropical gyre. See Wenneck et al. (2008) for additional sampling details, and Søiland et al. (2008) for hydrographic description.

In 2009 (from October 25 to November 29) the first oceanographic cruise of SA MAR-ECO was undertaken on the R/V Akademik Ioffe, between the latitudes $00^{\circ} 34^{\prime} \mathrm{S}$ and $33^{\circ} 40^{\prime} \mathrm{S}$. Ten Superstations were defined, distributed in three main domains stated in terms of the occurrence of the water masses: four in the South Equatorial MAR Sector (SEMS), influenced by the eastward inflow of the North Atlantic deep Water through the Equatorial Fracture (at depths of 1500-4000 m) and by the Antarctic Bottom Water's eastward inflow (at depths of more than $4000 \mathrm{~m}$ ). Two Superstations in the Tropical MAR Sector (TMS) influenced mainly by the North Atlantic deep Water's southward inflow, that is restricted by the Walvis Ridge and fills the Angola Basin almost exclusively. Finally, four Superstations in the Walvis Ridge Sector (WRS) influenced by the North Atlantic deep Water's southward inflow in the north (Angola Basin) and by the Antarctic Bottom Water's northward inflow in the south (Fig. 2). See Huang and Jin (2002) for hydrographic description. A total of 12 benthic sampling events, using a Sigsbee trawl, were conducted, five in the SEMS, two in the TMS and five in the WRS. During the same cruise 26 pelagic sampling events, using a Isaac-Kidd Midwater Trawl (IKMT) were undertaken, nine in the SEMS, five in the TMS and 12 in the WRS. The sampling events occurred at depths of from 902 to $4715 \mathrm{~m}$. 


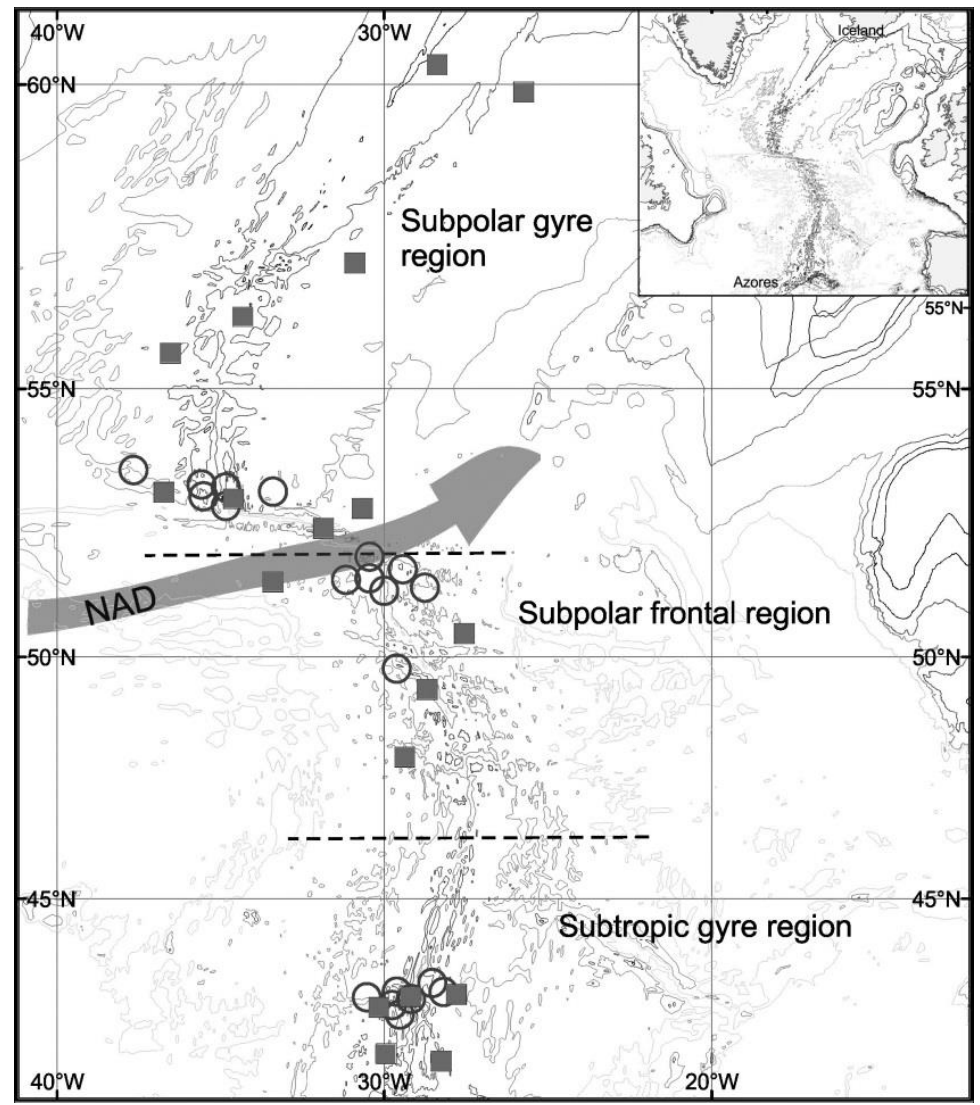

Fig. 1. Sample areas of North MAR. Pelagic (squares) and benthic (circles) samples.

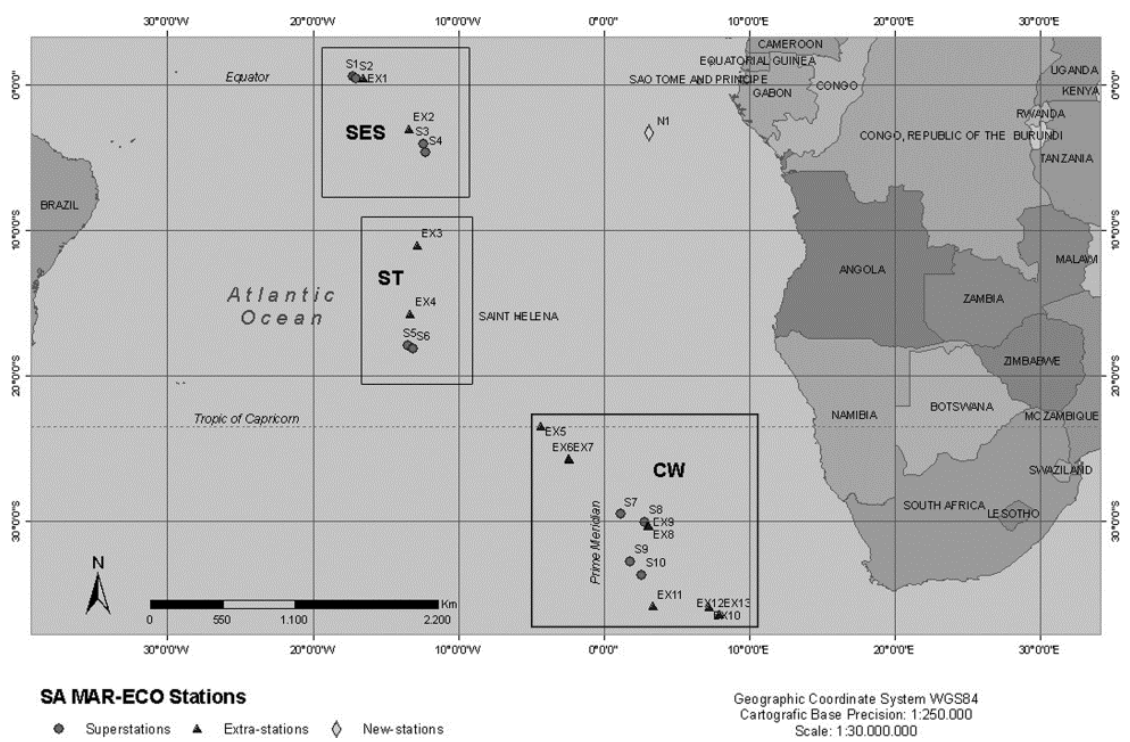

Fig. 2. Sample areas of South MAR. Only superstations (circles) were used herein. 
The specimens were fixed in $70 \%$ ethanol and identified to species level in the laboratory. The decapod material from the SA MAR-ECO expedition was deposited at the Crustacea collection of the Museu Nacional/Universidade Federal do Rio de Janeiro (MNRJ), Brazil; and the material from the R/V G.O. Sars expedition on the northern MAR was deposited at the Natural History Collections, University of Bergen, Norway.

In order to compare species richness between surveys, to estimate the total richness, and to evaluate the success of the sampling, the software EstimateS 8.0 (COLWELL, 2009) was used. The data analyzed were the total number of species found per trawl haul. The pattern of species accumulation (rarefaction) was examined using 500 randomizations to generate sample-based rarefaction curves (using the Mau Tao estimates of Sobs; COLWELL, 2009). Rarefaction requires some assumptions such as sufficient sampling and comparative sampling methods. As sampling methods and sampling effort differed between surveys, four separate curves were made, one for each sampling mode (pelagic or demersal) and region (northern or southern MAR).

Rarefaction curves allow comparison of species richness among surveys with different sampling efforts. To compare species richness, we truncated sampling effort to the smallest number of samples shared by all surveys. Estimates of the total species richness were calculated using the classic Chao 2 estimator. Chao 2 was chosen as nonparametric estimator as it performs well on small samples (COLWELL, 2009; COLWELL; CODDINGTON, 1994) and has been considered the least biased estimator dealing with total species richness (WALTHER; MOORE, 2005). The data sets were randomized 1000 times for estimation of loglinear $95 \%$ confidence intervals.

\section{RESULTS}

A total of 65 shrimp species (Table 1), 38 being Caridea and 27 Dendrobranchiata, were observed in the North MAR, while 50 species, 25 Caridea and 25 Dendrobranchiata, were observed in the South (Fig. 3).

Of the 12 Caridean and Dendrobranchiata families sampled, 10 were common to the two hemispheres. Despite this high level of homogeneity between South and North MAR at family level, in terms of species composition the two MAR hemispheres seem to be distinct, only 28 (32\%) of the 87 species sampled being shared (Table 1).

Only two new species were described for the MAR, one on the Northern MAR, the benthesicymid Altelatipes falkenhaugae Crosnier and Vereshchaka, 2008 and one on the southern MAR, the hippolytid Leontocaris smarensis Cardoso and Fransen, 2012 (CROSNIER; VERESCHAKA, 2008; CARDOSO; FRANSEN, 2012). As these two species have only recently been described, it is not possible to affirm that they are endemic to the MAR, thus sustaining the idea of a low level of endemism for this region.

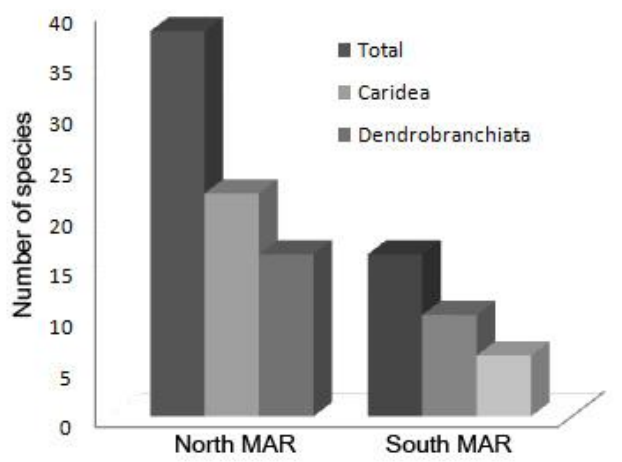

Fig. 3. Number of decapods shrimps species.

More than half of the species sampled (48 spp.; $57.8 \%$ ) (considering here only identifications at species level $=83$ spp.) present widespread distribution, occurring in more than one ocean; 22 of them in the Atlantic and Indian Oceans (including the Indo-Pacific region) and 26 reaching also the Pacific Ocean (thus being considered cosmopolitan) (Table 1). In contrast, $35 \mathrm{spp}$. (42.1\%) presented a restricted distribution, occurring only in the Atlantic Ocean (Table 1).

Interestingly, in both regions of the MAR, the deep sea pelagic family Oplophoridae was the most sampled group (Table 1, Figure 4). A total of 32 oplophorid species were sampled, 12 of which were shared between the two MAR hemispheres (Table 1). The greater part of the oplophorid species dealt with here were sampled only during pelagic trawls $(88 \%$ of the species sampled on the southern MAR and $80 \%$ on the northern MAR).

As regards the family Pasiphaeidae, a small number of species was sampled (Table 1, Fig. 4), but mainly in pelagic trawls (Table 1), thus confirming its pelagic habit. Six Pasiphaeidae species were sampled, all occurring on the northern MAR, only one being shared with the southern MAR (Table 1).

Considering the benthic family Nematocarcinidae, two species were sampled in each MAR hemisphere, but none was shared between them (Table 1). Two nematocarcinid species were sampled in demersal trawls on the southern MAR, and two species were also found by pelagic trawls on the northern MAR (Table 1). 
Table 1. Number of species by family sampled with the distinct sampling methods (DT - demersal trawls; PT - pelagic trawls; DPT - demersal and pelagic trawls).

\begin{tabular}{|c|c|c|c|}
\hline Classification & Occurrence at MAR & Distribution & Sampling method \\
\hline \multicolumn{4}{|l|}{ Suborder Dendrobranchiata } \\
\hline \multicolumn{4}{|l|}{ Family Aristeidae } \\
\hline Aristeus antennatus & North MAR & widespread & DT \\
\hline Austropenaeus nitidus & South MAR & restricted & DT \\
\hline Hepomadus tener & North MAR & widespread & DT \\
\hline Plesiopenaeus armatus & North MAR & widespread & DT \\
\hline \multicolumn{4}{|l|}{ Family Benthesicymidae } \\
\hline Altelatipes falkenhaugae & North MAR & restricted & PT \\
\hline Bentheogennema intermedia & North and South MAR & widespread & PT \\
\hline Bentheogennema sp. & South MAR & - & PT \\
\hline Benthesicymus brasiliensis & North MAR & restricted & DT \\
\hline Benthesicymus hjorti & North MAR & restricted & DT \\
\hline Gennadas brevirostris & South MAR & widespread & PT \\
\hline Gennadas capensis & South MAR & widespread & PT \\
\hline Gennadas elegans & North MAR & restricted & DPT \\
\hline Gennadas gilchristi & South MAR & restricted & DPT \\
\hline Gennadas parvus & South MAR & widespread & PT \\
\hline Gennadas scutatus & South MAR & widespread & DPT \\
\hline Gennadas talismani & South MAR & restricted & DPT \\
\hline Gennadas tinayrei & North and South MAR & widespread & PT \\
\hline Gennadas valens & North and South MAR & restricted & DPT \\
\hline \multicolumn{4}{|l|}{ Family Penaeidae } \\
\hline Funchalia villosa & North and South MAR & widespread & PT \\
\hline Funchalia woodwardi & North and South MAR & widespread & PT \\
\hline \multicolumn{4}{|l|}{ Family Sergestidae } \\
\hline Deosergestes corniculum & North and South MAR & restricted & DPT \\
\hline Deosergestes henseni & North and South MAR & restricted & DPT \\
\hline Parasergestes armatus & North and South MAR & widespread & PT \\
\hline Petalidium $s p$. & South MAR & - & $\mathrm{PT}$ \\
\hline Sergestes arcticus & North MAR & widespread & DPT \\
\hline Sergestes atlanticus & North and South MAR & widespread & DPT \\
\hline Sergestes pectinatus & North MAR & widespread & PT \\
\hline Sergestes sargassi & North MAR & widespread & PT \\
\hline Sergestes vigilax & North MAR & widespread & PT \\
\hline Sergia creber & South MAR & widespread & PT \\
\hline Sergia grandis & North and South MAR & restricted & DPT \\
\hline Sergia japonica & North MAR & widespread & DPT \\
\hline Sergia laminatus & South MAR & restricted & PT \\
\hline Sergia robusta & North and South MAR & restricted & DPT \\
\hline Sergia splendens & North and South MAR & widespread & PT \\
\hline Sergia tenuiremis & North and South MAR & restricted & DPT \\
\hline \multicolumn{4}{|l|}{ Family Solenoceridae } \\
\hline Hymenopenaeus chacei & North MAR & restricted & DT \\
\hline Hymenopenaeus laevis & North and South MAR & widespread & DT \\
\hline \multicolumn{4}{|l|}{ Suborder Pleocyemata } \\
\hline \multicolumn{4}{|l|}{ Infraorder caridea } \\
\hline \multicolumn{4}{|l|}{ Family Crangonidae } \\
\hline Sabinea sp. & North MAR & - & DT \\
\hline Parapontophilus abyssi & South MAR & widespread & DT \\
\hline Parapontophilus longirostris & South MAR & widespread & DT \\
\hline \multicolumn{4}{|l|}{ Family Hippolytidae } \\
\hline Leontocaris smarensis & South MAR & restricted & DT \\
\hline
\end{tabular}


Table 1. Continuation.

\begin{tabular}{|c|c|c|c|}
\hline \multicolumn{4}{|l|}{ Family Glyphocrangonidae } \\
\hline Glyphocrangon longirostris & North MAR & restricted & DT \\
\hline Glyphocrangon sculpta & North MAR & restricted & DT \\
\hline \multicolumn{4}{|l|}{ Family Nematocarcinidae } \\
\hline Nematocarcinus agassizii & South MAR & restricted & DT \\
\hline Nematocarcinus ensifer & North MAR & widespread & PT \\
\hline Nematocarcinus exilis & North MAR & restricted & DPT \\
\hline Nematocarcinus faxoni & South MAR & restricted & DT \\
\hline \multicolumn{4}{|l|}{ Family Oplophoridae } \\
\hline Acanthephyra acanthitelsonis & South MAR & restricted & DPT \\
\hline Acanthephyra acutifrons & North MAR & widespread & DT \\
\hline Acanthephyra brevirostris & North MAR & widespread & DPT \\
\hline Acanthephyra eximia & North MAR & widespread & DT \\
\hline Acanthephyra curtirostris & North and South MAR & widespread & PT \\
\hline Acanthephyra gracilipes & North MAR & restricted & DPT \\
\hline Acanthephyra microphthalma & North MAR & restricted & DT \\
\hline Acanthephyra pelagica & North and South MAR & widespread & DPT \\
\hline Acanthephyra purpurea & North MAR & restricted & DPT \\
\hline Acanthephyra quadrispinosa & South MAR & restricted & DPT \\
\hline Acanthephyra stylorostratis & South MAR & widespread & $\mathrm{PT}$ \\
\hline Ephyrina benedicti & North and South MAR & widespread & PT \\
\hline Ephyrina bifida & North MAR & restricted & DPT \\
\hline Ephyrina figueirai & North MAR & restricted & $\mathrm{PT}$ \\
\hline Ephyrina ombango & North MAR & widespread & PT \\
\hline Heterogenys monnioti & South MAR & restricted & DT \\
\hline Hymenodora sp. & North MAR & - & DT \\
\hline Hymenodora gracilis & South MAR & widespread & DPT \\
\hline Kemphyra corallina & North and South MAR & restricted & DT \\
\hline Meningodora compsa & North MAR & restricted & PT \\
\hline Meningodora miccyla & North MAR & widespread & PT \\
\hline Meningodora mollis & North MAR & widespread & DPT \\
\hline Meningodora vesca & North and South MAR & widespread & DPT \\
\hline Notostomus elegans & North and South MAR & widespread & PT \\
\hline Notostomus gibbosus & North and South MAR & widespread & DPT \\
\hline Notostomus robustus & North and South MAR & restricted & PT \\
\hline Oplophorus novazeelandiae & South MAR & widespread & PT \\
\hline Oplophorus spinosus & North and South MAR & widespread & DPT \\
\hline Systellaspis braueri & North MAR & restricted & DPT \\
\hline Systellaspis cristata & North and South MAR & widespread & $\mathrm{PT}$ \\
\hline Systellaspis debilis & North and South MAR & widespread & DPT \\
\hline Systellaspis pellucida & North and South MAR & widespread & DPT \\
\hline \multicolumn{4}{|l|}{ Family Pandalidae } \\
\hline Stylopandalus richardii & North and South MAR & widespread & PT \\
\hline \multicolumn{4}{|l|}{ Family Pasiphaeidae } \\
\hline Eupasiphae gilesi & North MAR & widespread & PT \\
\hline Parapasiphae sulcatifrons & North and South MAR & widespread & DPT \\
\hline Pasiphaea ecarina & North MAR & restricted & DT \\
\hline Pasiphaea hoplocera & North MAR & widespread & $\mathrm{PT}$ \\
\hline Pasiphaea multidentata & North MAR & restricted & DPT \\
\hline Pasiphaea tarda & North MAR & widespread & PT \\
\hline
\end{tabular}




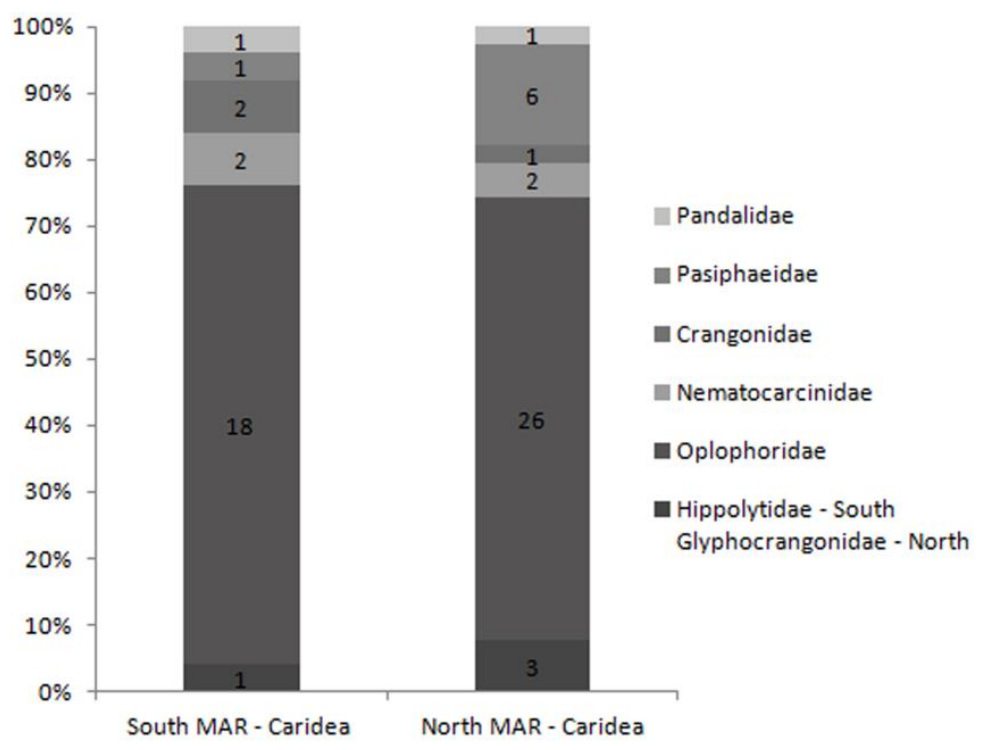

Fig. 4. Caridean families composition (number of species are inside the graph).

Only one species of Pandalidae was sampled in the present study, occurring on both the southern and northern MAR (Table 1): Stylopandalus richardii (Coutiére, 1905) that was only sampled during pelagic trawls (Table 1).

Crangonidae and Glyphocrangonidae are benthic and all the species sampled on the southern and northern MAR were caught by demersal trawls (Table 1). No crangonid species were shared between South and North MAR (Table 1) and the family Glyphocrangonidae was sampled only on the northern MAR (Table 1). The only Caridean family sampled exclusively on the South MAR was Hippolytidae (Table 1) - a highly diverse group with pelagic and benthic members occurring in shallow and deep waters. The hippolytid species sampled on the South MAR is benthic (sampled during demersal trawls), typical of deep sea coralline habitats.

Regarding the Dendrobranchiata fauna, five families were sampled in both MAR hemispheres (Fig. 5). On the southern MAR most benthesicymid species are members of the pelagic genus Gennadas (8 species), all of them sampled during pelagic trawls (Table 1). On the northern MAR, members of the benthic genus Benthesicymus were sampled in demersal trawls while species of the Gennadas and other genera were sampled in pelagic trawls (Table 1). Of the 14 benthesicymid species sampled during this study, only three were shared between the two hemispheres (Table 1).

The Sergestidae, represented here by the deep sea, pelagic genera Deosergestes, Parasergestes,
Sergestes and Sergia, occurred in both MAR hemispheres, but were more diverse on the northern MAR (Table 1, Figure 5). On the southern MAR all but one species were sampled in pelagic trawls, thus confirming its habit. The exception was one juvenile specimen of Sergestes atlanticus sampled by demersal trawl. On the northern MAR about half of the species were sampled only by pelagic trawls and the others by both pelagic and demersal trawls (Table 1). Of the 16 species sampled, 8 were shared between the two MAR hemispheres (Table, 1).

Members of Aristeidae were only caught in demersal trawls in this study (Table 1) and no species was shared between the southern and northern MAR. In this study two species of the solenocerid genus Hymenopenaeus were sampled during demersal trawls, one of them was shared between the two MAR hemispheres, the cosmopolitan Hymenopenaeus laevis (Bate, 1881) (Table 1).

It is interesting to observe that only two species sampled during this study with demersal trawls were shared between the southern and northern MAR (Table 1). The great majority of species shared between the two MAR hemispheres were sampled during pelagic trawls (26 spp. / 92.8\%) and present widespread distribution (20 spp. / 71.4\%) (Table 1). Species sampled only with demersal trawls (23 spp.), that probably present a predominantly benthic habit, are usually of restricted distribution (13 spp. / 56.5\%) (Table 1), while species sampled during pelagic trawls (64 spp.) usually present widespread distribution (42 spp. / 65.6\%) (Table 1). 


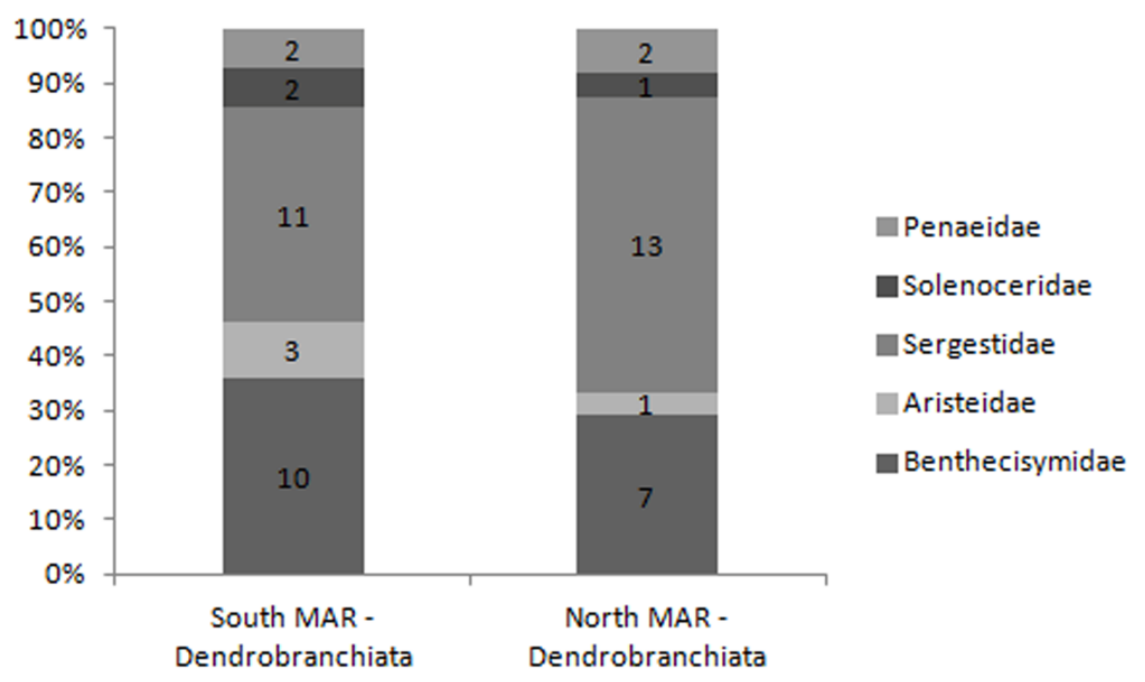

Fig. 5. Dendrobranchiata families composition (number of species are inside the graph).

The rate of species accumulation differed between sampling modes and regions (Fig. 6). Pelagic samples from the northern MAR were close to an asymptote (Fig. 6), indicating that we are close to the true number of pelagic shrimp species for this region. Pelagic samples from the southern MAR presented the greatest slope, suggesting that in this region we are still far from the true number of species (Fig. 6).

Estimated species richness (Chao-2 estimator) in the pelagic trawls on the northern MAR is 53 (mean of 1,000 resampling runs, $95 \%$ C.I. 51 68; Figure 7, Table 2), which is very close to the observed number of species (50).

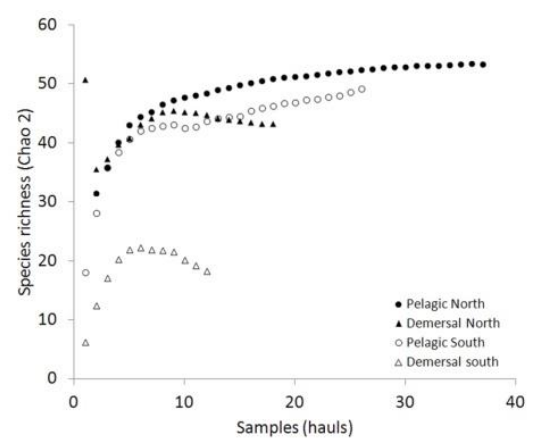

Fig. 6. Species rarefaction curves (Mau Tao) for pelagic trawls and demersal trawls in northern and southern MAR, based on 500 replicate randomizations.

Neither the estimated total species richness in pelagic trawls on the southern MAR, nor the demersal trawls in either region reached an asymptote (Fig. 6) and they demonstrated a wide 95\% CI (Table 2 ), suggesting that the estimates of total community diversity would likely be higher with greater sampling (Fig. 7).

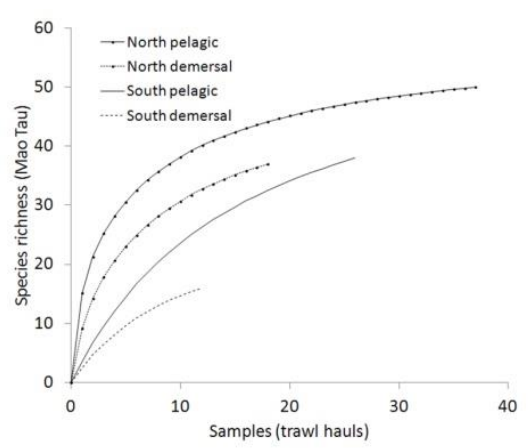

Fig. 7. Classic Chao-2 estimates of total species richness (1000 randomizations).

Table 2. Decapods species richness on northern and southern MAR, determined by pelagic and demersal sampling.

\begin{tabular}{lccc}
\hline \hline & $\begin{array}{c}\text { Observed } \\
\text { species richness } \\
\left(\mathrm{S}_{\text {obs }}\right)\end{array}$ & $\begin{array}{c}\text { Estimated } \\
\text { total species } \\
\text { richness } \\
\text { (Classic Chao 2) }\end{array}$ & $\begin{array}{c}95 \% \mathrm{CI} \\
(1000 \\
\text { replicates })\end{array}$ \\
\hline $\begin{array}{l}\text { Pelagic } \\
\text { North }\end{array}$ & 50 & 53 & $51-68$ \\
$\begin{array}{l}\text { Demersal } \\
\text { North }\end{array}$ & 37 & 43 & $39-93$ \\
$\begin{array}{l}\text { Pelagic } \\
\text { South }\end{array}$ & 38 & 49 & $41-76$ \\
$\begin{array}{l}\text { Demersal } \\
\text { South }\end{array}$ & 16 & 18 & $16-30$ \\
\hline
\end{tabular}


Summing up the estimates for both the pelagic and demersal trawls within each region, we arrived at a greater total Chao-2 estimate of diversity than with the total data set, reflecting an overlap in pelagic and demersal species associations (Table 2).

A comparison of species richness at 12 samples (smallest number of samples shared by all surveys) revealed that the pelagic species richness was greater than the demersal, and that the northern MAR contained a larger number of species than the southern.

\section{Discussion}

Considering that only $32 \%$ of the species sampled were shared by both MAR hemispheres we consider that the Equatorial Fracture zone may be acting as a biogeographical barrier for benthic decapod shrimps on the MAR. For pelagic shrimps the eastward flow of ABW through the EF strongly modifies water properties due to intense vertical mixing (FERRON et al., 1998; DEMIDOV et al., 2006) and also may be acting as a biogeographical barrier.

The high level of endemism attributed by Rogers (2004) to seamounts in general, and also expected for the MAR, has not here been confirmed, as only two new species were described for the region.

For the great majority of species the sample method used in this survey confirmed the life habit predominantly benthic or pelagic known to the literature (CROSNIER, 1978; CROSNIER; FOREST, 1973; CHACE, 1986; BAUER, 2004). Some cases, where the sample method used here reveals a different life habit for a family from that already known (Sergestidae may be taken as an example), can be explained by a behavior pattern relatively common to many deep sea shrimps, i.e., vertical migration: many of them live in the mud or soft sand during the daytime and perform vertical migrations up into the water column during the night to feed.

It is important to note that the data analyzed here are but a small piece in the huge puzzle of the distributional patterns existing on the MAR. The results may, even so, be used as a starting point for thinking about the biogeographical barriers and connections between the Southern and Northern MAR.

\section{AcKNOWLEDGEMENTS}

We are grateful to numerous MAR-ECO cruise participants who sorted and identified crustacean catches. We thank H. Ø. Hansen, M. Christiansen and A. Vereshchaka for their help with the identification of samples from the G.O. Sars 2004 expedition, and to Angel Perez for coordinating the South Atlantic MAR-ECO initiative. This study was supported in part by the MAR-ECO project within the framework of the Census of Marine Life Programme (CoML, www.coml.org).

\section{REFERENCES}

BAUER, R. T. Remarkable shrimps: adaptations and natural history of the carideans. Norman: University of Oklahoma Press, 2004. 282 p. (Animal natural history series, v. 7).

COLWELL, R. K.; CODDINGTON, J. A. Estimating terrestrial biodiversity through extrapolation. Philos. Trans. R. Soc., B., v. 345, n. 1311, p. 101-118, 1994.

CARDOSO, I. A.; FRANSEN, C. H. J. M. A new species of the deepwater shrimp genus Leontocaris (Hippolytidae: Caridea) from the South Mid-Atlantic Ridge. J. Mar. Biol. Assoc. U. K., v. 92, n. 5, p. 1083-1088, 2012.

CHACE, F. A. The Caridean shrimps (Crustacea: Decapoda) of the Albatross Philippine Expedition, 1907-1910, part 4: families Oplophoridae and Nematocarcinidae. Washington: Smithsonian Institution Press, 1986. 92 p. (Smithsonian Contributions to Zoology, v. 432).

CROSNIER, A. Crustacés décapodes pénéides aristeidae (Benthesicyminae, Aristeinae, Solenocerinae). Paris: Office de la Recherche Scientifique et Technique OutreMer, 1978. p. 197 (Faune de Madagascar, v. 46).

CROSNIER, A.; FOREST, J. Les crevettes profondes de l'Atlantique oriental tropical. Paris: Office de la Recherche Scientifique et Technique Outre-Mer, 1973. 409 p. (Faune Tropicale, v. 19).

CROSNIER, A.; VERESCHAKA, A. Altelatipes falkenhaugae n. gen., n. sp. (Crustacea, Decapoda, Benthesicymidae) de la ride médio-atlantique nord. Zoosystema, v. 30, n. 2, p. 399-411, 2008.

DE GRAVE, S.; FRANSEN, C. H. J. M. Carideorum catalogus: the recent species of the dendrobranchiate, stenopodidean, procarididean and caridean shrimps (Crustacea: Decapoda). Zool. Med. Leiden, v. 85, n. 9, p. 195-589, 2011.

DEMIDOV, A. N.; MOROZOV, E. G.; NEIMAN, V. G. Structure and variability of deep waters in the Romanche Fracture Zone. Dokl. Earth Sci., v. 410, n. 1, p. 11361140, 2006.

FARFANTE, I. P.; KENSLEY, B. Penaeoid and Sergestoid shrimps and prawns of the world: keys and diagnoses for the families and genera. Washington: National Museum of Natural History, 1997. 233 p. (Memoires du Museum National d'Histoire Naturel; v. 175).

FERRON, B.; MERCIER H.; SPEER K.; GARGETT, A.; POLZIN, K. Mixing in the Romanche fracture Zone. J. Phys. Oceanogr., v. 28, p. 1929-1945, 1998.

HUANG, R. X.; JIN, X. Deep circulation in the South Atlantic induced by bottom-intensified mixing over the midocean ridge. J. Phys. Oceanogr., v. 32, p. 11501164, 2002.

ROGERS, A.D. The biology of seamounts. Adv. Mar. Biol., v. 30, p. 305-350, 1994. 
SØILAND, H.; BUDGELL, W. P.; KNUTSEN, O. The physical oceanographic conditions along the Mid Atlantic Ridge north of the Azores in June-July 2004. Deep Sea Res., Part II, v. 55, n. 1/2, p. 29-44, 2008.

WALTHER, B. A.; MOORE, J. L. The concepts of bias, precision and accuracy, and their use in testing the performance of species richness estimators, with a literature review of estimator performance. Ecography, v. 28, n. 6, p. 815-829, 2005. COLWELL, R. K. EstimateS 8.2 user's guide. 2009. Available In: http://viceroy.eeb.uconn.edu/estimates. Accessed on: March 19, 2013.
WENNECK, T. L.; FALKENHAUG, T.; BERGSTAD, O. A. Strategies, methods, and technologies adopted on the R.V. G.O. Sars MAR-ECO expedition on the Mid Atlantic Ridge in 2004. Deep Sea Res., Part II, v. 55, n. 1/2, p. 6-28, 2008.

(Manuscript received 27 March 2013; revised 15 December 2013; accepted 21 January 2014) 